\title{
Numerical simulations of dual fuel combustion in a heavy duty compression ignition engine
}

In this study dual fuel direct injection was studied in terms of utilizing in compression ignition engines gaseous fuels with high octane number which are stored in liquid form, specifically liquid propane. Due to the fact that propane is not as much knock-resistant as natural gas, instead of conventional dual fuel system a system based on simultaneous direct injection of two fuel was selected as the most promissing one. Dual fuel operation was compared with pure diesel operation. The performed simulations showed huge potential of dual fuel system for burning light hydrocarbons in heavy duty compression ignition engines. However, further secondary fuel injection system optimization is required in order to improve atomization and lower the emissions.

Key words: Dual fuel, propane, LPG, direct injection, heavy-duty engine.

\section{Symulacje numeryczne jednoczesnego spalania dwóch paliw w silniku o zapłonie samoczynnnym dużej mocy}

W niniejszej pracy rozważono dwupaliwowy układ zasilania oparty na bezpośrednim wtrysku dwóch paliw w kontekście wykorzystania gazowych paliw o dużej liczbie oktanowej, mianowicie propanu, w silnikach o zapłonie samoczynnym. Z uwagi na fakt, iż propan nie jest tak odporny na spalanie stukowe jak metan, zamiast konwencjonalnego układu dwupaliwowego taczacego wtrysk bezpośredni $i$ pośredni zdecydowano się na zastosowanie koncepcji zasilania opartej na bęzpośrednim wtrysku dwóch paliw. Praca silnika w trybie dwupaliwowym została porównana z praca wytacznie na oleju napędowym. Przeprowadzone symulacje pokazały duży potencjat układów dwupaliwowych $w$ kontekście wykorzystania lekkich węglowodorów w silnikach o zapłonie samoczynnym dużej mocy. Niemniej jednak, dalsza optymalizacja układu paliwowego jest niezbędna aby poprawić proces rozpylenia paliwa i obniżyć emisje.

Stowa kluczowe: silnik dwupaliwowy, propan, LPG, wtrysk bezpśredni, silnik dużej mocy

\section{Introduction}

Dual fuel combustion, after certain slowdown again begins to be widely investigated. In the last decades the application of dual fuel combustion was mainly limited to diesel ignited stationary gas engines. However, due to emissions limits dual fuel engines becomes introduced into the marine applications. It is caused by more and more restrictive emissions limits (Tier II and Tier III standards of International Maritime Organization [1]). The engine manufacturers are developing new solutions, which will make possible meeting these standards, and one of these solution is the dual fuel technology. As for the engines in operation the situation is even more difficult. In order to meet strict emissions limits of NOx, CO, PM and SOx, there will be need to switch from conventional fuels to the cleaner ones. In this case the dual fuel technology will be the only option.

Moreover there is a strong need to implement dual fuel engines into the heavy duty vehicles and machinery markets.

One needs to be aware that dual fuelling concept can be implemented in different ways. The most common, prospective or under investigation by number of researchers systems used in compression ignition engines are:

- System combining port fuel addition and DI (Direct Injection)

- Simultaneous direct injection of two different fuels

System combining port fuel admission and direct injection can be arranged in two ways. Fuel can be added into intake port either by Port Fuel Injection (PFI) or by central mixing device. System based on central mixing device is in general predecessor of that one based on PFI, and this solution was replaced by the later one. Nevertheless, due to its simplicity and relatively low cost it is still commercially available and under further development and investigation [2], [3].

System based on PFI and DI has been investigated, developed and implemented especially in the area of stationary diesel ignited natural gas engines [4]. This solution was also applied to natural gas traction engines [5]. In this concept natural gas, which has high octane number, is fumigated in the intake manifold and the small amount of diesel fuel injected directly into cylinder is used as a reliable 
ignition source. This system is suitable for natural gas due to its high octane number. For gases with lower octane number the compression ratio of the engine needs to be decreased.

The promising concept of the fuelling process which could allow using fuels with low ability to autoignite is a simultaneous direct injection of both, the alternative fuel and conventional diesel fuel.

This solution has been investigated experimentally and numerically only with respect to gaseous fuel as a primary fuel [6-8]. Moreover, this system for gaseous fuel as a primary one has been already implemented for heavy duty vehicles by Westport company and for stationary engines by Wärtsilä.

This solution has made possible using as a fuel even associated gases of almost any quality [9]. This kind of fuelling concept has one serious disadvantage in case using gaseous fuels. Compressing a gaseous fuel up to a few hundred bar requires high amount of energy.

In this study the potential of this fuelling concept to utilize liquid propane is investigated. The main advantage of this solution, when compared with system for fuel in gaseous form, is the fact that the energy required for increasing the pressure of a liquid up to desired level is much lower than in case of gas. Moreover, the system for two liquid fuels could be complementary to the existing ones (based on direct injection of both: liquid and gas).

\section{Computational model}

\subsection{Turbulence model}

Presented simulations were done with the use of AVL Fire 2014, a CFD (Computational Fluid Dynamics) software based on finite volume method.

Turbulences were averaged using RANS (Reynolds Averaged Navier-Stokes) method. In general, the global flow characteristics such as spray and vapour penetration, liquid length, ignition delay, flame liftoff length, heat release rates, pressure traces etc., can be fairly well predicted by a RANS approach [10]. This method is the most commonly used one in commercial CFD codes due to its relatively low computational demands. Therefore this approach was used in this study.

Using RANS method results in necessity of using the closure model for so-called Reynold's stresses. There are several turbulence models proved to be reliable. In presented simulations the $\mathrm{k}-\zeta$-f model was used. This model was developed by Hanjalic et al. [11]. This model performs very well in regions, where velocity gradients are very high. These conditions were expected near the cylinder wall due to rotational movement of the charge and around nozzles. Therefore, this model was chosen for the simulations.

\subsection{Spray model}

There are two approaches to spray modeling, One is called Euler-Euler and the second one is Euler-Lagrange. In Euler-Euler approach, the different phases are treated mathematically as interpenetrating continua. Euler-Euler approach is most suitable for dense sprays where the spray may be well described by low number of phases. In EulerLagrange droplets are tracked in a Lagrangian way through the computational domain. This approach was firstly used in a stochastic form for liquid sprays by Dukowicz [12]. It allows to significantly reduce computational demands. It results from the fact that the droplets of the same properties are collected in a groups (parcels). The parcels are introduced into the domain with initial conditions of position, size, velocity, temperature and number of particles in the parcel.

Beside the way of representation of the multiphase flow, the droplet breakup is the most important element of spray modeling. According to Pilch and Erdman [13], there are different mechanisms of droplet breakup, which are dependent on the Weber number. For high pressure direct injection, where the Webber number is very high, catastrophic breakup mechanism is expected to govern the droplet breakup. In such conditions the most suitable breakup model is the Wave model. This model is based on the Kelvin-Helmholtz instability of a liquid jet, where the viscous forces produce waves on the liquid surface and new droplets are formed from the surface waves. Waves grow on the droplet surface with a certain rate and a wave length. The sizes of the newly-formed droplets are determined from the wave length and growth rate of this instability [14].

\subsection{Combustion model}

In this study ECFM-3Z (Extended Coherent Flame Model - 3 Zones) model was used. The common feature of Coherent Flame Models is the assumption that a turbulent flame is a collection of laminar flamelets, for which the thickness and the laminar flame speed of the flame are constant along the front of the flame and depend only on temperature, pressure and fuel concentration in the mixture. This approach is very convenient due to separation of chemical kinetics and turbulence. To couple the turbulence with the chemical kinetics the flame surface density parameter $(\Sigma)$ is used, for which additional transport equation is solved. In general the average reaction rate is modeled as follows [15]:

$$
\overline{\dot{\omega}}=\dot{\Omega} * \Sigma
$$

Where $\dot{\Omega}$ is the local rate of combustion per unit volume and integrated in the normal direction to the surface of the flame. 
Specific feature of ECFM-3Z model is the division the computational cell into 3 zones (fuel, air and mixture) which is a serious advantage over its predecessors especially when diffusion flames are concerned.

Beside the combustion model additional reaction were included in order to account the nitrogen oxides formation. In this study Extended Zeldovich model was used, which is based on the model proposed by Zeldovich [16].

\subsection{Computational Mesh}

The computational domain included full cylinder geometry. Neither intake nor exhaust ports were included. Real engine geometry was used to compose the computational mesh. The constructed mesh included the piston movement.

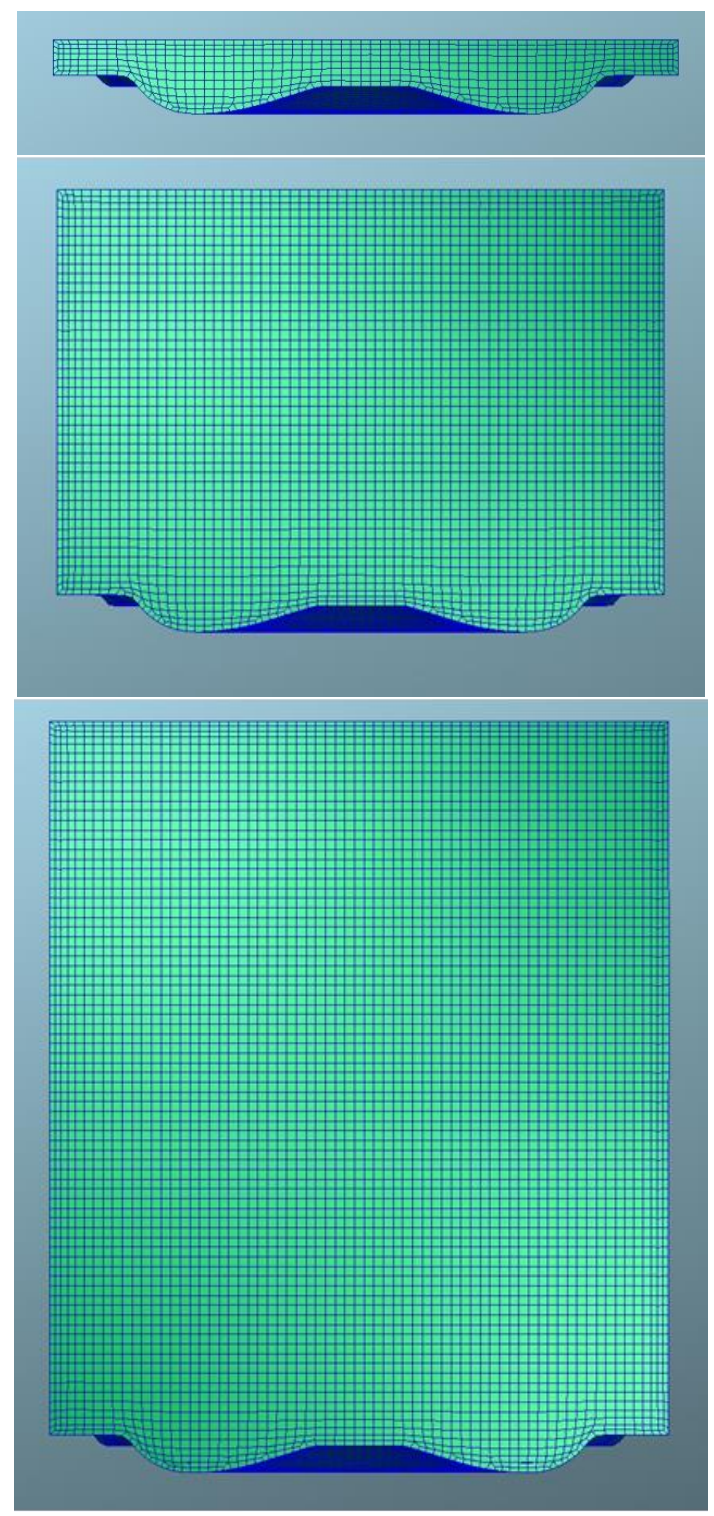

Fig. 1. Cross-section of the computational mesh at 180, 90 and 0 crank angle degrees before TDC, respectively from the bottom.
The geometrical parameters of the engine cylinder and selected engine parameters needed to create the deforming mesh are presented in Table 1.

Table 1. Parameters of the engine used for creating the computational mesh

\begin{tabular}{|l|c|}
\hline \multicolumn{1}{|c|}{ Parameter } & Value \\
\hline Cylinder bore & $320 \mathrm{~mm}$ \\
\hline Stroke & $350 \mathrm{~mm}$ \\
\hline Conrod length & $740 \mathrm{~mm}$ \\
\hline Compression ratio & 13.8 \\
\hline
\end{tabular}

The computational mesh was created using elements of maximum size of $5 \mathrm{~mm}$. Mesh was made in order to avoid strong stretching and compression of the mesh elements during the mesh deformation according to piston movement. Thus the number of mesh elements was dependent on time. The crosssection of the computational mesh showing its division into elements at different crank angles is presented in Fig. 1.

The created mesh at BDC consisted of 300000 elements, among which majority was of hexahedral shape. There was also low number of tetrahedron, pyramid and prism elements. One outer layer of the elements was created along the outer surface. Mesh at TDC (Top Dead Centre) consisted only of 33000 elements.

\subsection{Initial and boundary conditions}

The aim of the study was to investigate the combustion process and mixture formation in the dual fuel engine employing simultaneous direct injection of two different fuels (conventional diesel and propane). This investigation was based on comparison with the conventional CI (Compression Ignition) engine. Therefore two cases were calculated: DF (Dual Fuel) and pure diesel.

Most of the parameters characterizing the engine work were the same in both cases. The engine speed, compression ratio and the amount of energy provided in the fuel were exactly the same. The engine speed was of $750 \mathrm{rpm}$. The other parameters like, start of injection, injection duration, initial temperature and pressure were set according to the measured values on engine dyno. Due to the fact that the geometrical model didn't included the intake ports, and the intake stroke wasn't simulated, the rotational charge motion was applied as an initial condition. The initial rotational speed of the air in the chamber was set to $1125 \mathrm{rpm}$. The rotational movement was a swirl-type. The detailed 
initial conditions in calculated cases are presented in Table 2.

Table 2. Summary of analyzed cases

\begin{tabular}{|l|c|c|}
\hline \multicolumn{1}{|c|}{ Parameter } & $\begin{array}{c}\text { Case 1 } \\
\text { Dual fuel }\end{array}$ & $\begin{array}{c}\text { Case 2 } \\
\text { Diesel }\end{array}$ \\
\hline $\begin{array}{l}\text { Chamber pressure at } \\
\text { BDC }\end{array}$ & $0.35 \mathrm{MPa}$ & $0.35 \mathrm{MPa}$ \\
\hline $\begin{array}{l}\text { Chamber tempera- } \\
\text { ture at BDC }\end{array}$ & $343 \mathrm{~K}$ & $343 \mathrm{~K}$ \\
\hline $\begin{array}{l}\text { Start of diesel fuel } \\
\text { injection (before } \\
\text { TDC) }\end{array}$ & $12.5 \mathrm{CAdeg}$ & $12.5 \mathrm{CAdeg}$ \\
\hline $\begin{array}{l}\text { Start of n-hexane } \\
\text { injection (before } \\
\text { TDC) }\end{array}$ & $12.5 \mathrm{CAdeg}$ & - \\
\hline $\begin{array}{l}\text { Duration of diesel } \\
\text { fuel injection }\end{array}$ & $4 \mathrm{CAdeg}$ & $28.5 \mathrm{CAdeg}$ \\
\hline $\begin{array}{l}\text { Duration of } \\
\text { n-hexane injection }\end{array}$ & $20 \mathrm{CAdeg}$ & - \\
\hline $\begin{array}{l}\text { Injected mass of } \\
\text { Diesel (per cycle, } \\
\text { per cylinder) }\end{array}$ & $0.17 \mathrm{~g}$ & $3.644 \mathrm{~g}$ \\
\hline $\begin{array}{l}\text { Injected mass of } \\
\text { Hexane (per cycle, } \\
\text { per cylinder) }\end{array}$ & $0.465 \mathrm{~g}$ & - \\
\hline
\end{tabular}

\section{Results}

The obtained results were analyzed starting from the in-cylinder pressure curves. Altough the amount of energy delivered in fuel was the same for both cases (DF and diesel) the pressure curves were different. The pressure evolution in comnustion chamber is presented in Fig. 2. One needs to be awere that initial pressure (at BDC) was much higher for DF mode. This difference resulted from the engine-turbocharger system specific response to DF operation. Therefore the compression curve for diesel oparation is below the curve for DF mode. Higher initial pressure in DF corresponds to the difference in peak pressures (just after TDC).

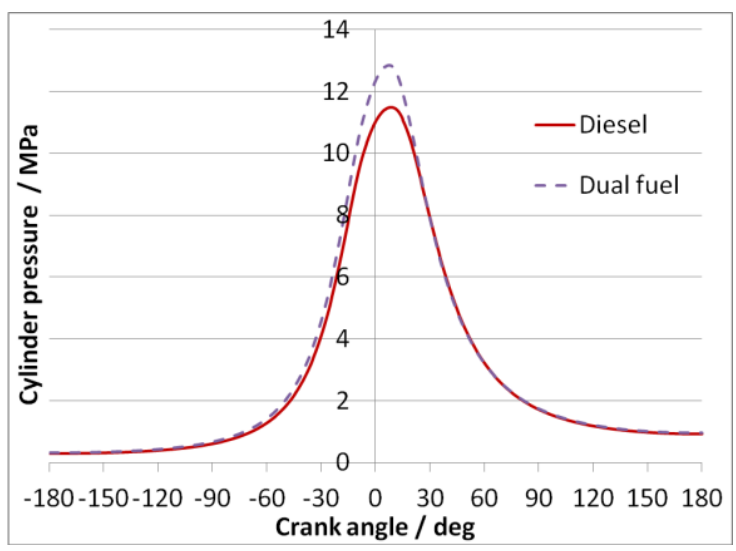

Fig. 2. Cylinder pressure for dual fuel and pure diesel operation
The indicated work of one cycle was of $44.26 \mathrm{~kJ}$ and $41.05 \mathrm{~kJ}$ for diesel and DF operation respectively. Asuming 4 cylinder 4-stroke engine this results in engine indicated power of $1106 \mathrm{~kW}$ and $1026 \mathrm{~kW}$ respectively. Taking into account that in both cases the same amount of energy was delivered during the cycle this clearly shows that the energy conversion efficiency for DF mode is lower than for diesel mode, even though the peak pressure was higher.

In order to see the dynamics of the combustion process the rate of heat release was shown in Fig. 3.

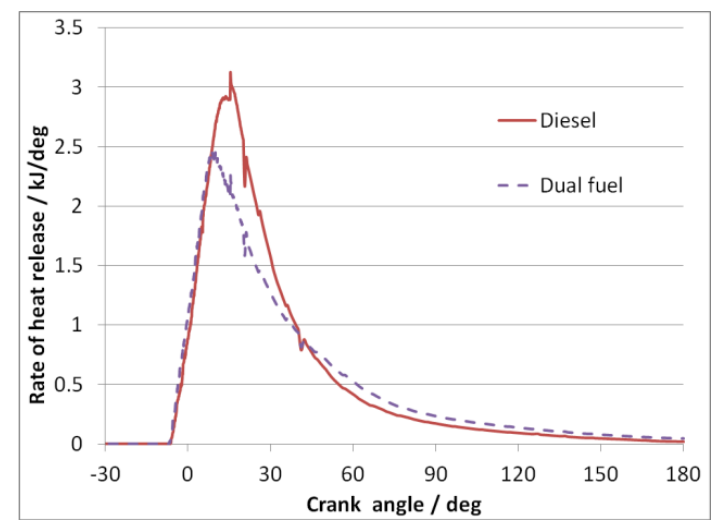

Fig. 3. Rate of heat release for dual fuel and pure diesel operation

In Fig. 3. one can clearly see that the rate of heat release for diesel mode was more rapid. The higher peak in rate of heat release corresponds to higher efficiency in diesel mode.

Cumulated heat release also differs between the DF and diesel modes. as shown in Fig. 4.

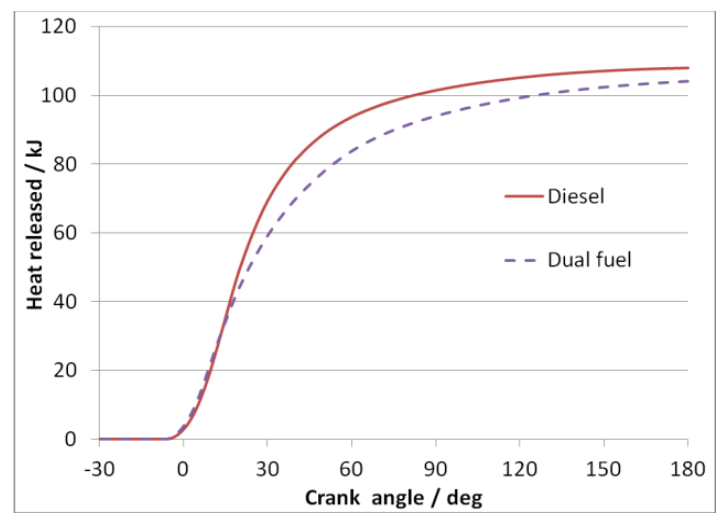

Fig. 4. Cumulated heat release for dual fuel and pure diesel operation

The noticed differences in combustion dynamics could results from mixture formation. Therefore the spray formation was presented in Figs. 5. and 6., and in Figs. 7. and 8. The intention of presenting these results is to give qualitative view on the spray formation in different fuelling modes rather than quantitative comparison. 


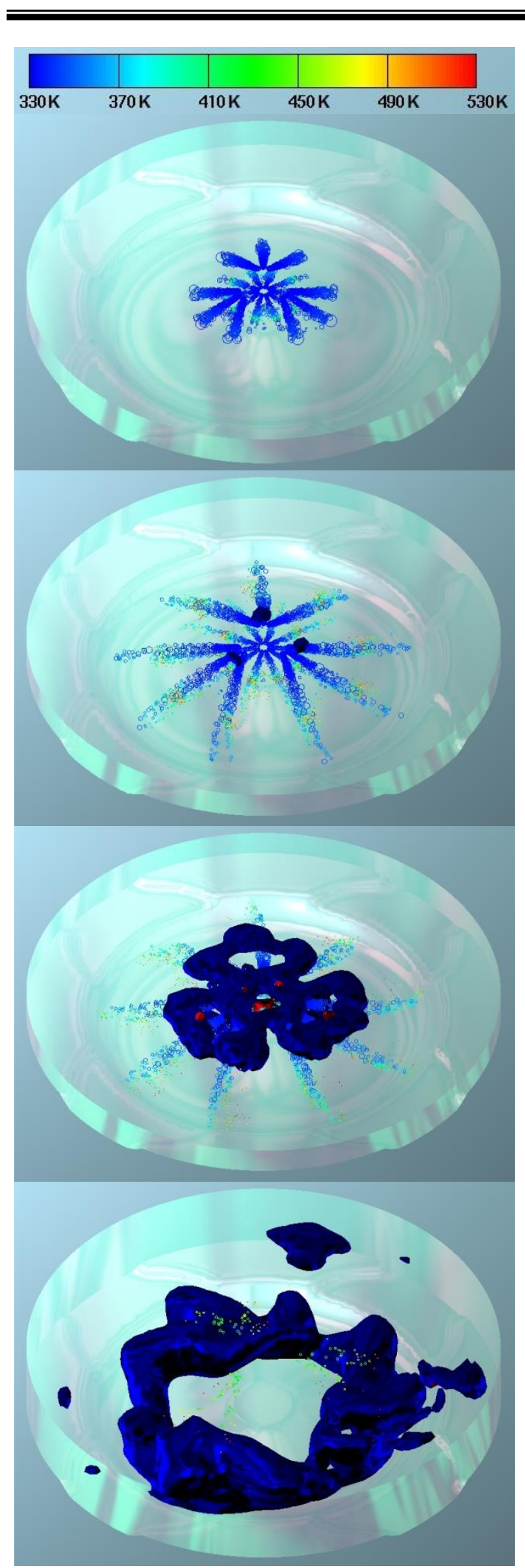

Fig. 5. Spray evolution (fuel droplets colored by fuel temperature) and $\mathrm{OH}$ radicals mass fraction iso-surface (3e-5) at -10, -5, 0 and 30 deg after $T D C$ respectively from the top for DF mode

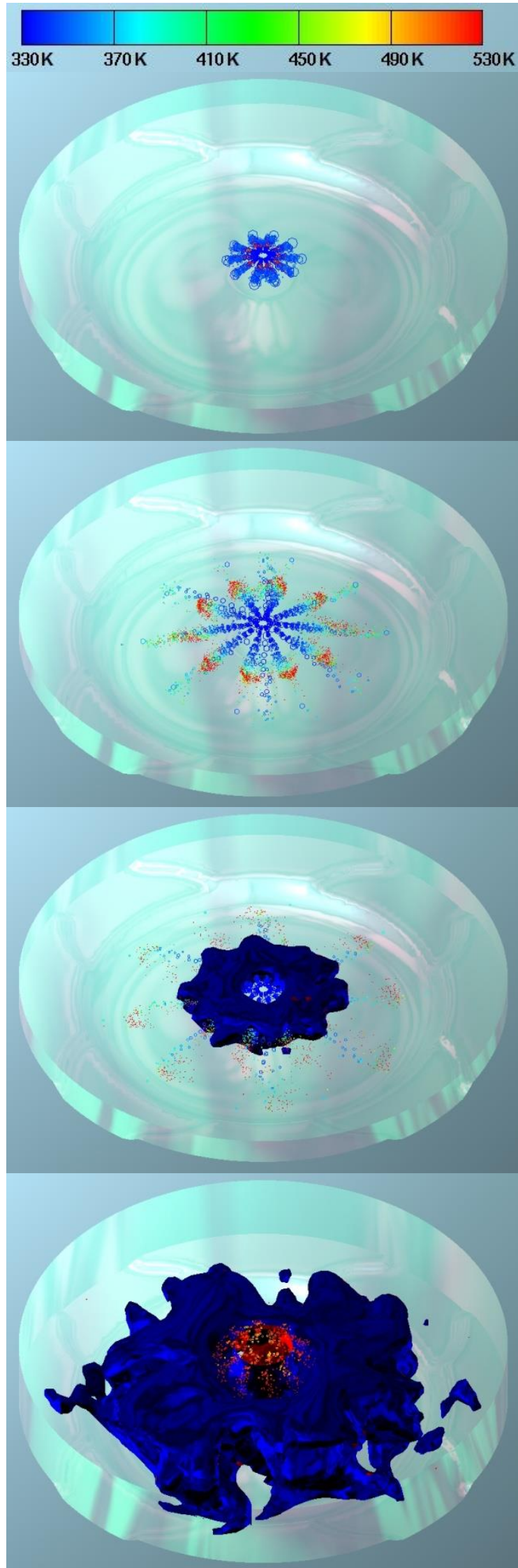

Fig. 6. Spray evolution (fuel droplets colored by fuel temperature) and $\mathrm{OH}$ radicals mass fraction iso-surface (3e-5) at -10, -5, 0 and 30 deg after TDC respectively from the top for diesel mode 


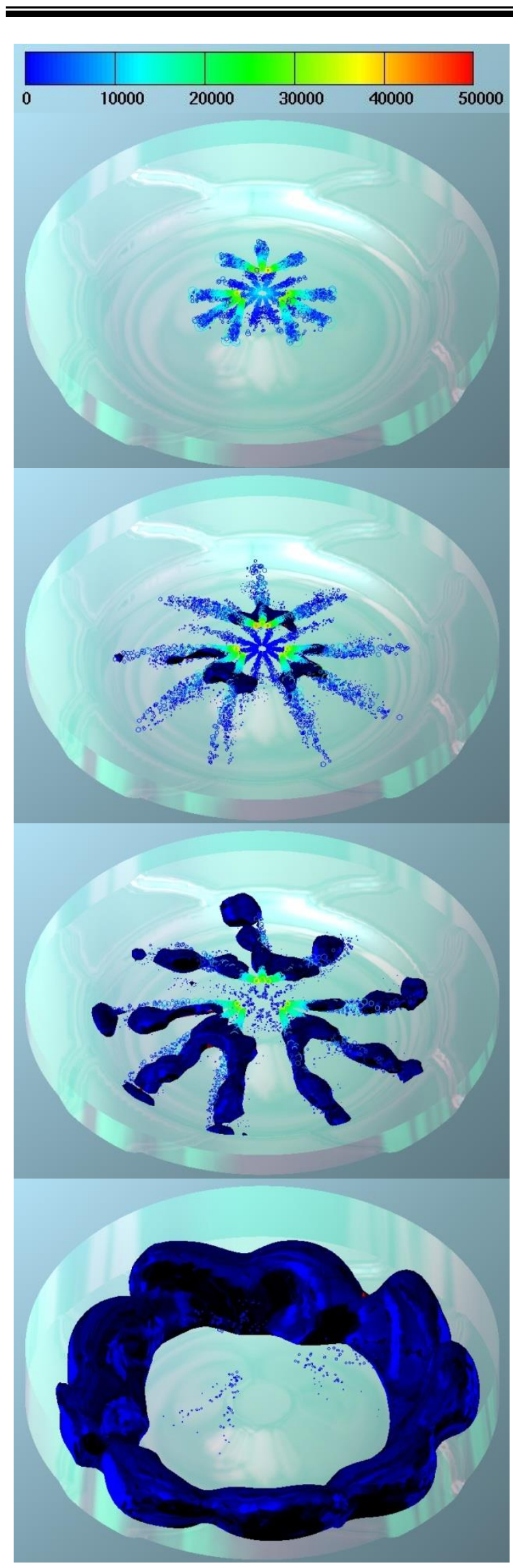

Fig. 7. Spray evolution (fuel droplets colored by Weber number) and mixture formation (stoichiometric iso-surface) at -10, -5, 0 and 30 deg after $T D C$ respectively from the top for $D F$ mode

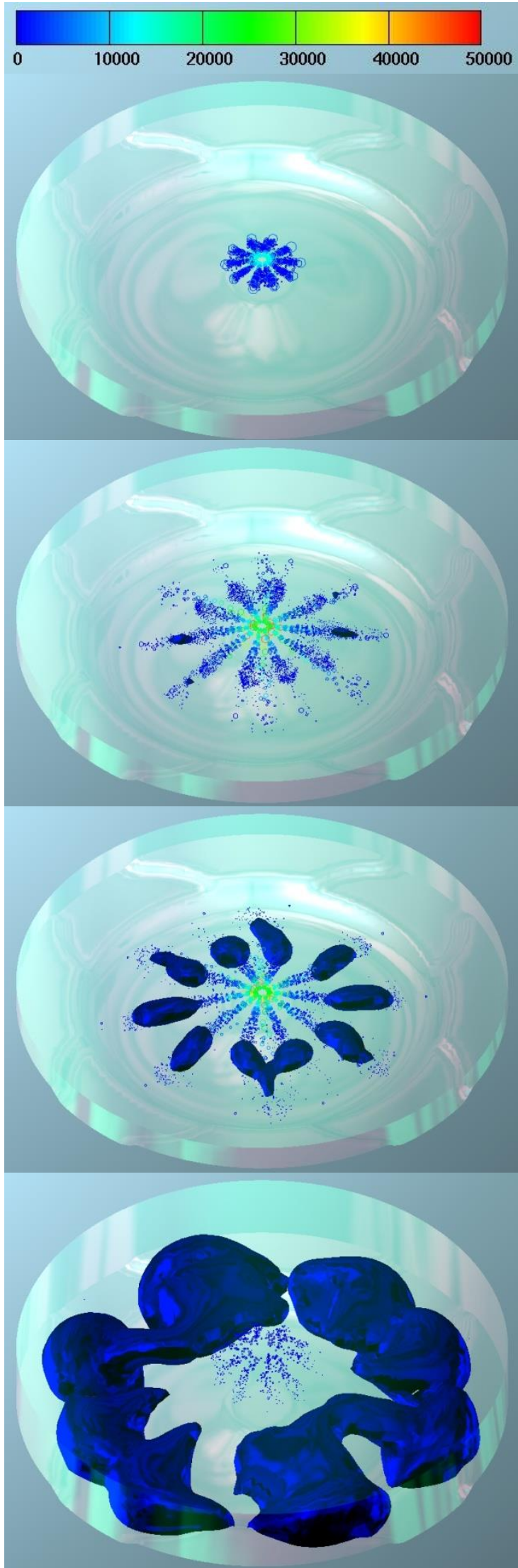

Fig. 8. Spray evolution (fuel droplets colored by Weber number) and mixture formation (stoichiometric iso-surface) at -10, -5, 0 and 30 deg after $T D C$ respectively from the top for diesel mode 
In Figs. 5. and 6. the droplets were collored by a liquid phase temperature. In Figs. 7 . and 8 . by Weber number. More important element presented in Figs 5. and 6. is the $\mathrm{OH}$ radicals mass fraction iso-surface. The iso-surface value was set to $3 e-5$. The $\mathrm{OH}$ radical directly correspond to the reaction zone. In Figs 7. and 8. the iso-surface represents the soichiometric mixture. One needs to be aware that the angle intervals between images are not equal and were specified that way deliberately in order to show different steps of mixture formation.

The average droplet diameter for the whole computational domain is presented in Fig. 9.

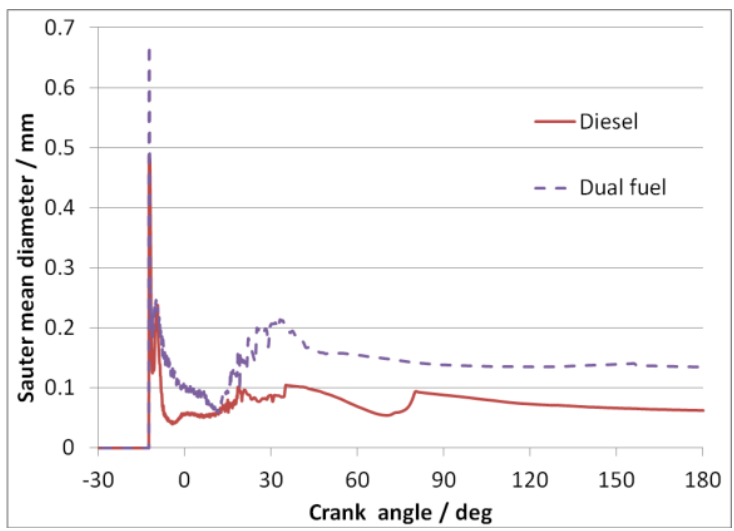

Fig. 9. Droplet diameter (Sauter) for dual fuel and pure diesel operation

The average droplet diameter for diesel mode was lower than for DF mode during almost entire period (shown in Fig. 9.). The bigger droplets are usually reason for prolonged combustion. What could be the reason also in this case. In order to confirm this assumption the process of injection and evaporation was compared. It is shown in Fig. 10.

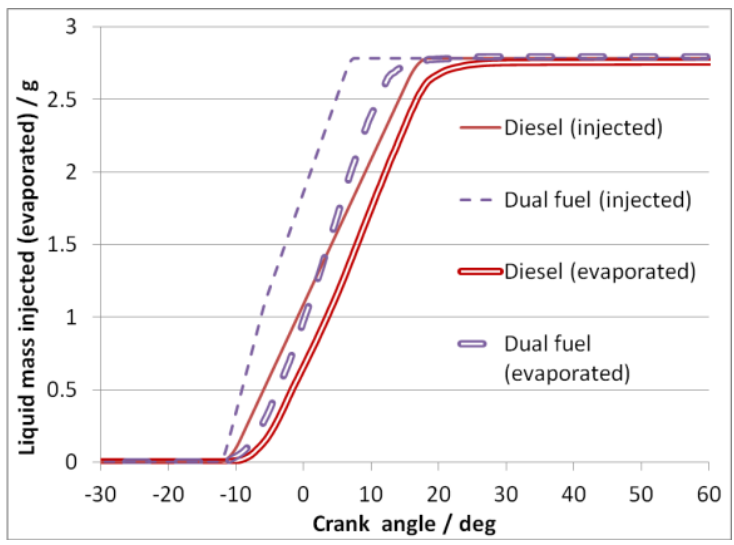

Fig. 10. Injected and evaporated liquid for dual fuel and pure diesel operation

Injection process was much faster in DF mode what results from the fact that the mass flow throgh the propane nozzle was higher and that in DF mode and at the beginning of the injection process liquid fuels are injected through two pairs of nozzles. The distance between the curves presenting mass evaporated and mass injected in Fig. 10 directly reflects the time needed for fuel to evaporate. One can notice that this time is longer for DF mode than for diesel operation.

Additionaly NO mass fraction was shown in order to see the potential of meeting the NOx limits by the DF engine (Fig. 11.).

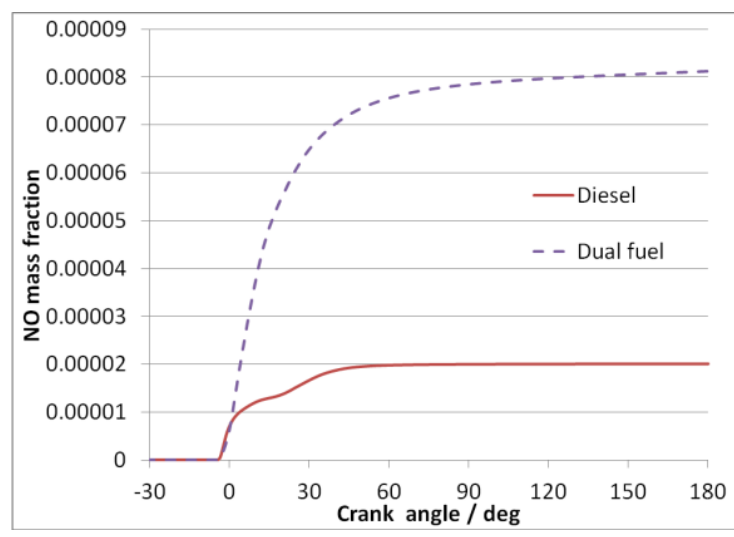

Fig. 11. NO mass fraction in cylinder for dual fuel and pure diesel operation

The NO formation for DF was much higher for DF mode what clearly shows that the DF system needs further improvement.

\section{Conclusions}

Numerical simulations were performed in order to compare the combustion process and mixture formation in novel duel fuel system with the conventional single fuel CI engine operating on diesel fuel. The obtained results were analyzed and following conclusions were made:

- The DF mode resulted in higher peak pressure although the combustion process was prolonged. This resulted from the fact that initial pressure (pressure at BDC) was higher

- Energy conversion efficiency for DF mode was lower than for diesel mode.

- The prolonged combustion can be linked with poor fuel atomization. The time needed for fuel to evaporate in DF mode was much higher than for diesel mode

- The NO formation for DF was much higher thab for diesel mode what clearly shows that the DF system needs further improvement

In general one can conclude that there is a huge potential of dual fuel system for burning light hydrocarbons in heavy duty compression ignition engines. However, in order to improve fuel atomization and mixture formation further fuel injection system optimization is required. 


\section{Nomenclature/Skróty i oznaczenia}

BDC Bottom Dead Centre / dolne martwe położenie

CFD Computational Fluid Dynamics / obliczeniowa mechanika płynów

CI Compression Ignition / o zapłonie samoczynnym

CNG Compressed Natural Gas / sprężony gaz ziemny

DF Dual Fuel / dwupaliwowy
DI Direct Injection / wtrysk bezpośredni

ECFM-3Z Extended Coherent Flame Model - 3 Zones / model ECFM-3Z

LPG Liquified Petrolum Gas / gaz skroplony

PFI Port Fuel Injection / wtrysk do kanatu dolotowego

RANS Reynolds Averaged Navier-Stokes / Uśrednienie Reynoldsa równań Naviera-Stokesa

TDC Top Dead Centre / górne martwe położenie

\section{Bibliography/Literatura}

[1] International Maritime Organization. RESOLUTION MEPC.251(66). THE MARINE ENVIRONMENT PROTECTION COMMITTEE; 2014.

[2] Bedoya ID, Arrieta AA, Cadavid FJ. Effects of mixing system and pilot fuel quality on diesel-biogas dual fuel engine performance. Bioresour Technol 2009;100:6624-9.

[3] Sun J, Bittle JA, Jacobs TJ. Influencing Parameters of Brake Fuel Conversion Efficiency with Diesel/Gasoline Operation in a Medium-Duty Diesel Engine. SAE Tech Pap 2013-01-0273 2013.

[4] Sahoo BB, Sahoo N, Saha UK. Effect of engine parameters and type of gaseous fuel on the performance of dual-fuel gas diesel engines-A critical review. Renew Sustain Energy Rev 2009;13:1151-84.

[5] Addy JM, Bining A, Norton P, Peterson E, Campbell K, Bevillaqua O. Demonstration of Caterpillar C10 Dual Fuel Natural Gas Engines in Commuter Buses. SAE Tech Pap 2000-01-1386 2000.

[6] White T, Milton B, Behnia M. Direct injection of natural gas/liquid diesel fuel sprays. Proc 15th Australas Fluid Mech Conf 2004.

[7] Dumitrescu S, Hill PG, Li G, Ouellette P. Effects of Injection Changes on Efficiency and Emissions of a Diesel Engine Fueled by Direct Injection of Natural Gas. SAE Tech Pap 200001-1805 2000.

Mr Kapusta Łukasz Jan, PhD Eng. Research Fellow in the Faculty of Power and Aeronautical Engineering at Warsaw University of Technology

Dr inż. Kapusta Lukasz Jan - Adiunkt na Wydziale Mechanicznym Energetyki $i$ Lotnictwa Politechniki Warszawskiej

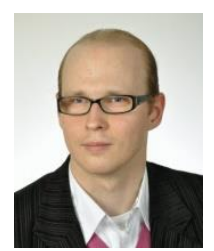

Mr Andrzej Teodorczyk, DSc., DEng. Professor in Faculty of Power and Aeronautical Engineering at Warsaw University of Technology.

Prof. dr hab. inż. Andrzej Teodorczykprofesor zwyczajny na Wydziale Mechanicznym Energetyki $i$ Lotnictwa Politechniki Warszawskiej.

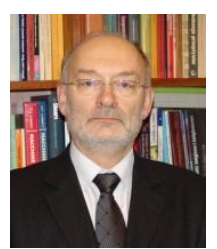

